\title{
Australian Bills of Rights: The ACT and Beyond: Lessons from New Zealand
}

\section{Dr Petra Butler, Victoria University of Wellington.}

It is a pleasure to be invited to offer a New Zealand perspective on the theme of today's conference: Australian Bills of Rights: ACT and Beyond. I have chosen to focus on two topics which, although distinct, have a number of points of cross-over. The first is the extent to which the "dialogue" model of human rights protection captures New Zealand experience under the New Zealand Bill of Rights Act 1990 (BORA). The second is a consideration of the jurisprudence on s 6 BORA- $s$ being the BORA provision which directs that a meaning of an enactment that is consistent with BORA is to be preferred whenever that meaning can be given.

Both of these topics seemed to be worth exploring today each for two reasons: First, in the debates on the ACT Human Rights Act 2004 (ACT HRA) and the proposed Victorian Charter of Rights and Responsibilities considerable attention has been given to both the "dialogue" model and to the potential use of a statutory direction to adopt rights-consistent meanings ("consistency direction"). ${ }^{1}$ Both of these are also features of the debate over and jurisprudence under BORA. Second, the New Zealand experience on both the "dialogue" model and the judicial use of the consistency direction is sufficiently different from that under the United Kingdom's Human Rights Act 1998 (UK HRA)- another system to which Australians have turned when discussing human rights protection- to be interesting.

\section{The Dialogue Model}

The ACT Bill of Rights Consultative Committee opined, when discussing the effect of the proposed Human Rights Act on the interaction of the three arms of government that it would reinforce a "dialogue" or institutional interaction between the different arms of government and the community. ${ }^{2}$ Chief Minister of the Act, Jon Stanhope, described the purposes of the ACT HRA, as his Government saw it, thus: ${ }^{3}$

\begin{abstract}
What we wanted to create was a rights consciousness that permeated public administration, a conversation between the executive and the legislature, between government and the judiciary, between the public service and the people”
\end{abstract}

Similarly, the Human Rights Consultation Committee in its report for the Victorian Government found that a "dialogue" model best reflected the wishes of the public- it would best ensure the involvement of all arms of government in the promotion of

\footnotetext{
${ }^{1}$ See, for example, Report of the ACT Bill of Rights Consultative Committee, Toward a ACT Human Rights Act (May 2003) 61 et seq. McIntosh, Legislative Assembly Daily Hansard (13.06.2006) 40; Watchirs “The ACT Human Rights Act 2004: Its Impact and Potential” speech delivered at the Australian National University Toyota Public Lecture Series, the Australian National University (22.02.2005) 2 .

2 ACT Bill of Rights Consultative Committee, Report of the ACT Bill of Rights Consultative Committee: Toward a ACT Human Rights Act (Canberra, May 2003) 61 para 4.5.

${ }^{3}$ Chief Minister Jon Stanhope, speech at the Act Human Rights Community Forum (1.05.2006) 2.
} 
human rights. ${ }^{4}$ Its proposals for a Victorian Charter of Rights and Responsibilities seek to achieve this aim.

However, the Consultative Committee described the dialogue as not open-ended since, after debate, the legislature was assigned the last say in relation to human rights issues. To create a dialogue, the judiciary could not be able to invalidate legislation but rather be able to give its opinion that a law is incompatible with the proposed Human Rights Act. It should then be a matter for the legislature to determine whether or not to amend the legislation so that it conforms to the proposed Human Rights Act. ${ }^{5}$ In this way, the "dialogue model" would best serve the democratic process in which it is in the realm of the legislature to be the final decision maker on human rights issues but on the other hand create an active role for the judiciary in the protection of human rights since the judiciary is perceived to be less swayed by immediate political agendas. ${ }^{6}$

The concept of a "dialogue" in the human rights field is not new. In 1997 Peter Hogg and Alison Bushell first examined the concept of a "dialogue" between courts and Parliament. ${ }^{7}$ They showed that the argument that judicial review of legislation under the Canadian Charter of Rights and Freedoms was illegitimate (because it was undemocratic by undermining parliamentary sovereignty) was in practical terms incorrect. Hogg and Bushell revealed that Charter cases nearly always could be, and often were, followed by new legislation that accomplished the same objectives as the legislation that was struck down by the Supreme Court taking into account the Court's findings. ${ }^{8}$ However, their analysis only concerned Canada which has a constitutional set up which gives the Supreme Court the mandate to strike down legislation. Does the dialogue model work for a parliamentary bill of rights system?

In my view the "dialogue" concept is usually just as apposite, if indeed not more so, in respect of a statutory bill of rights system precisely because each of the actors has a substantial freedom within its sphere. ${ }^{9}$ Under a supreme bill of rights system the ability of political arms to directly challenge an unfavourable court decision is difficult (for example, a constitutional amendment to undermine a court decision is usually difficult to achieve), meaning that they must either accept the decision and incorporate it into the legal regime, or seek to tinker with it at the margins. Under a parliamentary bill of rights Parliament can, if it wishes, reverse the court through the ordinary legislative processes.

\footnotetext{
${ }^{4}$ Human Rights Consultation Committee, Rights, Responsibilities and Respect- Report of the Human Rights Consultation Committee (Melbourne, November 2005) chapter 4.

${ }^{5}$ Report of the ACT Bill of Rights Consultative Committee, Toward a ACT Human Rights Act (May 2003) 61 para 4.5.

${ }^{6}$ Report of the ACT Bill of Rights Consultative Committee, Toward a ACT Human Rights Act (May 2003) 61 paras 4.1. - 4.4.

${ }^{7}$ Hogg/Bushell "The Charter Dialogue Between the Courts and Legislature" (1997) 35 Osgoode Hall LJ 75.

${ }^{8}$ Hogg/Bushell "The Charter Dialogue Between the Courts and Legislature" (1997) 35 Osgoode Hall LJ 75, Hogg and Bushell surveyed 65 cases in which a law was struck down for a breach of the Charter. These included all of the decisions of the Supreme Court of Canada in which a law was struck down, as well as several important decisions of trial courts and courts of appeal which were never appealed to the Supreme Court of Canada, (see also fn 20).

${ }^{9}$ See P Butler "Human Rights and Parliamentary Sovereignty in New Zealand" (2004) 35 VUWLR 341.
} 
Turning to the position of the judges, as commentators such as Joseph, Rishworth, Gardbaum and others have emphasised, just because under a parliamentary bill of rights the courts cannot strike down legislation does not mean that judges cannot undertake a type of constitutional review: after all under a statutory bill of rights judges are typically empowered to interpret enactments in a bill of rights consistent way or can make declarations of inconsistency where the enactment unjustifiably trenches on fundamental rights (and cannot be read down to achieve consistency) or can grant remedies for rights violations. ${ }^{10}$ In short, courts can form the judgements that courts operating under supreme bill of rights can- the only substantial constraint is what they can do in respect of some situations where a rights inconsistency is identified (viz. those where the inconsistency cannot be interpreted away).

Therefore, a parliamentary bill of rights system by its nature seems more likely to fit a dialogue model: after all Parliament by enacting the bill of rights not only makes clear that it supports human rights, but also states that it wants the courts to be a forum in which human rights issues can be considered. However, Parliament reserves its ability to react to a court decision on human rights as it sees best, having regard to political considerations. Equally, courts can form judgements on human rights issues and through their reasoning can identify problems and resolve many (though not all).

\section{DIALOGUE "ON THE GROUND"}

The more interesting question that then arises is- given that a parliamentary bill of rights lends itself, in principle, to encouraging dialogue among the different arms of government- does a dialogue actually occur and, if so, what is the nature of that dialogue?

The New Zealand experience, in my view, does show that a genuine dialogue can exist. Under BORA the rights debate is not dictated solely by the courts. Parliament can disagree and has disagreed with BORA-based court decisions and has reacted by a range of measures: overruling, minimisation and so on. Equally, on other occasions the political arms have accepted judicial outcomes, even if only after a "robust debate". And the "robust debate" is an important point: it is not that Parliament must accept the expression of a judicial view- rather it chooses to accept the judicial view. Government has also been active, for example, when it formulates the terms of reference for the Law Commission to scrutinise issues which result from court decisions. ${ }^{11}$. And on some issues the approach of Government lawyers on human rights issues could be viewed as going further in terms of rights protection than that which the courts had seen as necessary. ${ }^{12}$

\footnotetext{
${ }^{10}$ Gardbaum “The New Commonwealth Model of Constitutionalism” (2001) 49 AJCompL 707, 741; P Rishworth “The Inevitability of Judicial Review under 'Interpretive' Bills of Rights” (2004) 23 SCLR 233, 266; Joseph “Constitutional Review Now” [1998] NZLRev 85.

11 See, for example, Law Commission, Defaming Politicians: A Response to Lange v Atkinson (NZLC R64, 23 Aug 2000); Law Commission, Habeas Corpus: Procedure (NZLC R 44, 20 Nov 1997).

${ }^{12}$ See below the discussion in regard to same-sex marriages.
} 


\section{Baigent's case}

One of the most famous BORA cases so far has been Baigent's case. Its fame rests on its establishment of a new public law-based cause of action that created a direct, rather than a vicarious, liability as against the Crown in case of violation of BORA. ${ }^{13}$ In the instant case the plaintiffs sought damages arising out of the obtaining and execution of a search warrant in respect of their residence. The plaintiffs pleaded that the police had obtained a search warrant to search their residence relying on incorrect information from an informant, and that when it was pointed out to them (when they came to execute the warrant), the police nonetheless continued with the search, with one of the officers allegedly saying "we often get it wrong, but while we are here we will have a look around anyway." 14 The plaintiffs pleaded that in entering, remaining on, or searching the property in all of those circumstances, the officers had unlawfully procured the search warrant, had been negligent, had committed a tort of trespass and also had violated the right of the plaintiffs to be secure against unreasonable search and seizure as protected by s 21 BORA. The Crown submitted that the courts had no jurisdiction to award damages for a violation of BORA since BORA did not provide any remedial power to judges in cases of violation. Secondly, the Crown submitted that even if the courts had jurisdiction to award damages for breach of BORA rights and freedoms, in the instant case such a proceeding was barred by the terms of s 6(5) of the Crown Proceedings Act $1950 .{ }^{15}$ The Court of Appeal, by majority, rejected both of these Crown's submissions. ${ }^{16}$

Judgment in Baigent was delivered on 29 July 1994. On 24 August 1994 the Minister of Police was asked whether the Minister had reviewed BORA and the recent Court of Appeal decisions in regard to the possibility that the police could be sued for breaching BORA. The question arose in relation to the alleged compulsory participation of suspects in police line ups and identification parades. The Minister of Police answered with a simple "no". ${ }^{17}$ However, the exchange does show that at least one Member of Parliament was aware of the significance of the Baigent decision.

In November 1995 the decision was mentioned in the Select Committee Report on the Courts and Criminal Procedure (Miscellaneous Provisions) Amendment Bill: ${ }^{18}$ "Earlier this year the Government made a number of decisions regarding the Baigent decision, and the Law Commission was invited to include issues relating to Crown liability under the New Zealand Bill of Rights 1990 in its general review of Crown liability, and to report to the Cabinet Strategy Committee by 1 March 1996.” Indeed

\footnotetext{
${ }^{13}$ See discussion of Baigent's case in P Butler "Human Rights and Parliamentary Sovereignty in New Zealand” (2004) 35 VUWLR 341, 348- 350.

${ }^{14}$ Simpson v Attorney-General (Baigent's case) [1994] 3 NZLR 667, (1994) 1 HRNZ 42 , 44 (CA).

${ }^{15}$ Crown Proceedings Act 1950 reads: "No proceedings shall lie against the Crown by virtue of this section in respect of anything done or omitted to be done by any person while discharging or purporting to discharge any responsibility of a judicial nature vested in him, or any responsibilities which he has in connection with the execution of judicial process.”

${ }^{16}$ See, for a detailed analysis of the judgment, Butler \& Butler, The New Zealand Bill of Rights Act 1990;: a commentary (Lexis Nexis, Wellington, 2005) paras 27.4.1 et seq.

${ }^{17}$ Hansard, Questions on Notice (24.08.1994) http://gphansard.knowledge-basket.co.nz (last accessed 15.06.2006).

${ }^{18}$ Alec Neill, Chairperson of the Justice and Law Reform Select Committee, Hansard (28.11.1995) http://gphansard.knowledge-basket.co.nz (last accessed 15.06.2006).
} 
the Law Commission ${ }^{19}$ published its report Crown Liability and Judicial Immunity- A Response to Baigent's Case and Harvey v Derrick in 1997. ${ }^{20}$ The Law Commission concluded that there should be no general legislation removing or circumscribing the remedy for breach of BORA, which Baigent's case held to be available. The Law Commission's conclusion in turn was considered by the Ministry of Justice without any further consequences. ${ }^{21}$

Since the Court of Appeal's decision in Baigent the courts have awarded BORA damages on a regular basis for violations of rights such as free movement, arbitrary arrest and unreasonable search and seizure. ${ }^{22}$ In a small number of cases, the award of damages has been controversial. In particular, controversy has attended settlements and court awards to prisoners for various human rights related violations they have suffered. The treatment of this issue illustrates dialogue at work (although not everyone may be impressed by the nature of the dialogue!). The recent compensation decisions include settlements with several of Mangiaroa Prison who were the subject of ill treatment, an amount of $\$ 60,000$ to an inmate who was held for 252 days more in prison than he should have been ${ }^{23}$ and even more importantly and most recently compensation of five maximum security prisoners who had been subjected to a Behaviour Management Regime which was held to be a violation of $\mathrm{s}$ 23(5) BORA. ${ }^{24}$ The, in New Zealand terms, relative high amount of compensation pay-out (in excess of $\$ 130,000$ ) in the latter case of Taunoa $v$ Attorney-General resulted in a public out-cry and came close to a media frenzy. ${ }^{25}$

Parliament reacted to the decision in Taunoa and introduced in 2004 the Prisoners and Victims' Claims Bill. The intention was to give victims priority where prisoners were awarded compensation as a result of BORA breaches whilst in detention. The Attorney-General's report under s 7 BORA stated that the bill was BORA-consistent. The Act came into force before an appeal to the Court of Appeal was decided. The Court of Appeal, being aware that awarding prisoner compensation was critically looked upon by Parliament, increased the amount of compensation in regard to one prisoner by $\$ 10,000$ to $\$ 65,000$ on appeal. Under the Prisoners and Victims' Claims Act 2005 the right of prisoners to compensation for violation of his or her BORA

\footnotetext{
19 The Law Commission is an independent, government-funded organisation, established under the Law Commission Act 1985, which reviews areas of the law that need updating, reforming or developing. It makes recommendations to Parliament, and these recommendations are published in its report series. The Law Commission receives references for work from the Government but also can self-refer issues for consideration.

${ }^{20}$ NZLCR 37 (Wellington 1997)

21 See Ministry of Justice, Corporate Plan 1997-99- Public Law, http://www.justice.govt.nz/pubs/reports (last accessed 16.06.2006).

${ }^{22}$ See, for example, Attorney-General v Upton (1998) 5 HRNZ 54 (CA); Innes v Wong (No 2) (1996) 4 HRNZ 247 (HC); see, for a full treatment, Butler \& Butler, The New Zealand Bill of Rights Act 1990: a commentary (Lexis Nexis, Wellington, 2005) chapter 27.

${ }^{23}$ Manga v Attorney-General (1999) 5 HRNZ 177 (HC).

${ }^{24}$ Taunoa v Attorney-General [2004] BCL 968 (HC). BORA, s 23(5) states "Everyone deprived of liberty shall be treated with humanity and with respect for the inherent dignity of the person."

25 See: The Dominion Post "Inmates accuse jail of mental torture" (21.10.2003) 4, http:helicon.vuw.ac.nz:2177 (last accessed 22.06.2006); The Dominion Post "Mistreated prisoners claim compo of \$605,000” (26.08.2004) 4, http:helicon.vuw.ac.nz:2177 (last accessed 22.06.2006); Tony Wall "Murderer's compo stuns widow" Sunday Star Times (5.09.2004) http:helicon.vuw.ac.nz:2177 (last accessed 22.06.2006); The South Land Times “To the victims go the spoils” (8.09.2004) http:helicon.vuw.ac.nz:2177 (last accessed 22.06.2006).
} 
rights while in prison is not removed; neither the Act "only" gives victims the right to participate in the proceeds of the rights violation.

\section{Martin}

Another area which is illustrative of how the three arms of government can interact with each other to avoid further BORA violations is the area of trial delay. The issue became public after the Court of Appeal in Martin $v$ District Court at Tauranga ${ }^{26}$ stayed the proceedings after a 17 months delay between the charge and the trial. Martin had been accused of three counts of sexual violation. The issue of trial delay became the subject of ministerial questions ${ }^{27}$ and the Courts and Criminal Procedure (Miscellaneous Provisions) Amendment Act which brought about changes to the court structure to avoid further stays of proceedings. In fact the decision led to the case management system undergoing an overhaul to make case management more efficient. All courts within the system scrutinised their procedure to avoid further delays. The problem of undue delay of trials resurfaced in 1997 when the increase of jury trials in the District Courts led to backlog and delay and the resulting of stay of proceedings because of it. Parliament enacted the Community Magistrates Act to ease the backlog and avoid stay of proceedings.

\section{Quilter}

Another landmark decision in an entirely different field resulted in all arms of government becoming active. In Quilter v Attorney-General the Court of Appeal was asked to extend the meaning of the Marriage Act 1955 to include same-sex couples so that they had the opportunity to get married. ${ }^{28}$ (Section 19 of BORA prohibits discrimination by reason of, inter alia, sexual orientation.) The Court unanimously found it not possible to interpret the Marriage Act 1955 in a way to include same-sex couples. In his judgment Tipping J explicitly stated: ${ }^{29}$

...it is highly unlikely that Parliament would have intended to make such a substantial change to one of society's fundamental institutions by the indirect route of [section] 19 and [section] 6 of the Bill of Rights.

His Honour clearly significant to Parliament that it was up to Parliament to change the legal situation of same-sex couples. The Court felt that a decision of such social importance should be made by the elected representatives of the people.

\footnotetext{
${ }^{26}$ (1995) 1 HRNZ 186 (CA).

27 Hansard (8.05.1995); Phil Goff, Second Reading of the Courts and Criminal Procedure (Miscellaneous Provisions) Amendment Bill, Hansard (5.12.1995); see also Select Committee Report for the Courts and Criminal Procedure (Miscellaneous Provisions) Amendment Bill, Hansard (28.11.1995).

${ }^{28}$ (1997) 4 HRNZ 170 (CA).

${ }^{29}$ Quilter v Attorney-General (1997) 4 HRNZ 170, 232 (CA, Tipping J).
} 
The case attracted some media attention. ${ }^{30}$ For large parts of New Zealand society the result of the case was not satisfactory. The decision led to the Ministry of Justice preparing a discussion paper on the treatment of same-sex couples under the law ${ }^{31}$ and the Law Commission publishing a study paper on similar issues. ${ }^{32}$ Furthermore, $^{2}$ from 2001, the Attorney-General - obviously herself picking up on international trends - began to report bills that did not treat equally opposite-sex and same-sex couples as being unjustified discrimination contrary to s 19 BORA. ${ }^{33}$ In 2004 the Civil Union Bill was introduced and passed. It came into force last year.

In sum, it took eight years from the Court of Appeal judgment in Quilter to the coming into force of the Civil Union Act 2004. This seems to be a long gestation period for an Act. However, remarkably the initiative was born out of a judgment that denied a part of society a "right" which large parts of society had. Led by the Ministry of Justice, a consultation process with all New Zealanders began which gave Government and Parliament the confidence to afford same sex couples the same rights as heterosexual couples.

\section{Pora and Poumako}

A final example of how the dialogue between Parliament and the courts has been conducted in New Zealand arises out of the cases of Poumako ${ }^{34}$ and Pora. ${ }^{35}$ These cases concerned the so-called "home invasion" legislation under which the minimum non-parole period for a home invasion murder was increased (retrospectively) from 10 to 13 years. This legislation was the reaction to a number of brutal murders and serious assaults on persons in their own homes. In Poumako and Pora the issue was the retrospectivity of the legislation. The difference between the two cases lay in the different periods at issue. In Poumako the majority found, albeit in an obiter dictum, that it had never been Parliament's intent to afford retrospective effect to the home invasion provisions. ${ }^{36}$ In Pora a similar question in regard to the same legislation arose. This time the Court divided three to three on whether fundamental rights can be impliedly repealed by later legislation. ${ }^{37}$ Interesting about the judgments is that some of the judges proclaimed that it could not have been Parliament's intent to pass a clause which clearly violated BORA despite the fact that the parliamentary debates showed that the fact that the clause would have detrimental retrospective effect had

\footnotetext{
30 See, for example:Vasil Anamika "Lesbians seek court ruling allowing them marital rights" The Dominion (26.02.1996) 3; The Dominion “Court rules against same-sex marriages” (29.05.1996) http//:helicon.vuw.ac.nz:2177 (last accessed 26.06.2006); The Dominion "Marriage campaigner hails report” (19.08.1997) http//:helicon.vuw.ac.nz:2177 (last accessed 26.06.2006); The Evening Post "Lesbian couples appeal gender-neutral Act” (3.09.1997) http://helicon.vuw.ac.nz:2177 (last accessed 26.06.2006); The Daily News "Lesbian couples press claim to marry" (4.09.1997) http//:helicon.vuw.ac.nz:2177 (last accessed 26.06.2006); The Dominion “Gay lobby group; to take fight to Parliament” (18.12.1997) http://helicon.vuw.ac.nz:2177 (last accessed 26.06.2006).

${ }^{31}$ Ministry of Justice, Same-Sex Couples and the Law (Wellington 1999).

${ }^{32}$ Law Commission, Recognising Same Sex Relationships, NZLC SP 4 (Wellington 1999).

${ }^{33}$ See, for example, Social Security (Residence of Spouses) Amendment Bill 2001, War Pensions Amendment Bill (No 2) 2001. For full list see the table in Butler \& Butler, The New Zealand Bill of Rights Act 1990: a commentary (Lexis Nexis, Wellington, 2005) 205, 206.

${ }^{34}$ [2000] 2 NZLR 695 (CA).

35 [2001] 2 NZLR 37 (CA).

${ }^{36} R$ v Poumako [2000] 2 NZLR 695 paras 36-41 (CA, Richardson P, Gault, Keith JJ).

${ }^{37}$ Richardson P reserved his decision on that issue: $R$ v Pora [2001] 2 NZLR 37 para 60 (CA).
} 
been brought to Parliament's intention. ${ }^{38}$ It took Parliament six months to react but eventually it repealed the retrospectivity provision.

\section{Statutory Interpretation according to Section 6}

\section{Introduction}

I would like now to have a closer look at the micro-level of human rights implementation in New Zealand. Section 30 of the ACT HRA instructs courts, tribunals, decision makers and others authorised to act by a Territory statute or statutory instrument that "when working out the meaning of a Territory law, an interpretation that is consistent with human rights is as far as possible to be preferred." 39 This consistency direction is similar to s 6 of BORA ${ }^{40}$ and s 3(1) of the UK Human Rights Act 1998 (HRA 1998). ${ }^{41}$ However, differently from s 6 BORA and s 3(1) HRA 1998, s 30 HRA in its subsections 2 and 3 gives some guidance as to how the ACT Legislature wanted the consistency direction to be approached:

(2) Subsection (1) is subject to the Legislation Act, section 139 [which requires the interpretation that would best achieve the purpose of a law to be preferred to any other interpretation (the purposive test)].

(3) In this section: working out the meaning of a Territory law means-

(a) resolving an ambiguous or obscure provision of the law; or

(b) confirming or displacing the apparent meaning of the law; or

(c) finding the meaning of the law when its apparent meaning leads to a result that is

manifestly absurd or is unreasonable; or

(d) finding the meaning of the law in any other case.

It will be interesting to see whether this direction by the ACT legislature will result in the adoption of robust criteria by the courts when undertaking an interpretation exercise. However, by subsections 3(b) and (c) the legislature appears to give the courts the mandate to alter the meaning of the law but without giving them any criteria to do so. In fact, the ACT HRA also it identifies the areas where the consistency direction will arise for consideration, does not provide criteria as to how within the areas a particular interpretation exercise had to be approached. As we shall see, the New Zealand courts have identified the same areas in which issues of consistency and proper use of the consistency direction will arise; but to date New Zealand courts have been unable to develop criteria how to exercise its interpretation mandate. $^{42}$

\footnotetext{
${ }^{38} R$ v Pora [2001] 2 NZLR 37 para 107 (Gault, Keith, McGrath JJ).

${ }^{39}$ HRA, s 30 does not state to whom the HRA applies. The Explanatory Statement, however, makes it clear that all three arms of government have to take the HRA into account [Legislative Assembly for the Australian Capital Territory, Human Rights Bill 2003, Explanatory Statement (http: \www.legislation.act.gov.au, last accessed 15.06.2006) cl 30.

${ }^{40}$ BORA, s 6 reads:" Whenever an enactment can be given a meaning that is consistent with the rights and freedoms contained in this Bill of Rights, that meaning shall be preferred to any other meaning."

${ }^{41}$ HRA 1998, s 3(1) states:” So far as it is possible to do so, primary legislation and subordinate legislation must be read and given effect in a way which is compatible with the Convention rights."

${ }^{42}$ See for an overview of the New Zealand experience: Butler \& Butler, The New Zealand Bill of Rights Act 1990: a commentary (Lexis Nexis, Wellington, 2005) chapter 7.
} 
In Australia, as well as in New Zealand and the United Kingdom, the respective consistency directions have resulted in numerous academic articles. ${ }^{43}$ And despite the fact that the idea behind "only" allowing the courts to interpret legislation consistently with the respective bills of rights (instead of allowing courts to strike down inconsistent legislation) has been to preserve parliamentary sovereignty, authors have questioned whether the courts have fulfilled their side of the bargain. ${ }^{44}$ Indeed, some have gone so far as to say of the New Zealand and British models: "Interpretation becomes a sort of Alice in Wonderland exercise." 45 "Judicial activism” via the tool of human rights consistent interpretation is another "swear term" used to describe the perception that some authors have from the human rights jurisprudence of the UK and New Zealand courts. ${ }^{46}$

In my view, however, it would be wrong to lump the New Zealand and the UK experience together-in fact the New Zealand experience is quite different from the UK's, especially in so far as how courts have understood their mandate to interpret legislation human rights consistent manner. In my opinion, the New Zealand experience is the more relevant one for an Australian audience. Let me explain.

Building on the discussion of the dialogue model discussed in the previous section, the dialogue (to the extent it happens through interpretation) in the UK is marked by the possibility that a person whose rights have been held to be violated by a UK statute can "appeal” to the European Court of Human Rights. The result in my view has been an aggressive application of the consistency direction in s 3 of the HRA 1998 with the result that there is less room for dialogue (the UK courts have been seen to be more "activist"). ${ }^{47}$

In contrast, New Zealand courts do not live under the shadow of the European Court of Human Rights. Communications to the UN Human Rights Committee from New Zealand have been few and only one has had (partial) success. Also, the exploited and seriousness of purpose that attended the enactment of the HRA 1998 had no equivalent in New Zealand. Quite the opposite. As is well known, the New Zealand

\footnotetext{
${ }^{43}$ See, for example, Australia: Cocoran, "The Architecture of Interpretation: Dynamic Practice and Constitutional Principles” in Coran/Bottomley (eds) Interpreting Statutes (Federation Press, Annandale NSW, 2005), Bronitt “The Human Rights Act 2004 (ACT)- A “Claytons Bill of Rights” or New Magna Carta?” (2004) 28 Criminal Law Journal 325; Debeljak "The Human Rights Act 2004 (ACT): A Significant, Yet Incomplete, Step Toward the Domestic Protection and Promotion of Human Rights" (2004) 15 Public Law Review 169; Minty, Saved by the Bill, research paper, ANU (June 2005); Winterton "The ACT Bill of Rights" (2004) 7 Constitutional Law and Policy Review 47.

New Zealand: Parkhill "Dethroning the Sovereign: Human Rights and State Sovereignty" [2002] NZSLJ 67; Elias "Sovereignty in the 21 ${ }^{\text {st }}$ Century: Another Spin on the Merry-Go-Around" (2003) 14 PLR 148; P Butler "Human Rights and Parliamentary Sovereignty in New Zealand" (2004) 35 VUWLR 341.

United Kingdom: Clayton "The Limits of what's Possible: Statutory Construction under the Human Rights Act” [2002] EHRLR 559; Gearty "Reconciling Parliamentary Democracy and Human Rights" (2002) 118 LQR 248.

${ }^{44}$ Smellie "'Fundamental Rights', Parliamentary Supremacy and the New Zealand Court of Appeal" (1995) 111 LQR 209; Gearty "Reconciling Parliamentary Democracy and Human Rights” (2002) 118 LQR 248.

${ }^{45}$ Sydney Morning Herald “All bets are off when a bill of rights comes in” (24.04.2006).

${ }^{46}$ Clayton "The Limits of what's Possible: Statutory Construction under the Human Rights Act” [2002] EHRLR 559; Allan "Moonen and McSense" [2002] NZLJ 142; Parkhill "Dethroning the Sovereign: Human Rights and State Sovereignty" [2002] NZSLJ 67.

${ }^{47}$ Lord Lester "Interpreting Statutes Under the Human Rights Act” (1999) 20 Stat LR 218.
} 
bill of rights started off as a proposed entrenched and supreme bill of rights with the courts having the power to strike down legislation. ${ }^{48}$ However, after extensive public consultation the government dropped the supreme law approach as it was thought of as anti-democratic, substituting unelected and unaccountable judges for elected politicians in the determination of many key political issues. ${ }^{49}$ Bora was enacted with little further public discussion or interest as an ordinary statute.

So what has been the New Zealand experience? Is it a really an "Alice in Wonderland exercise"? In my view, despite the odd bold judicial statement that might suggest that the courts would be prepared to prefer an interpretation that is directly contrary to that intended by Parliament, the courts have never gone so far (unlike their UK counterparts) and, indeed, have often downplayed the role that can legitimately be played under s 6 BORA.

\section{Section 6 in the Courts}

In its first BORA case, Flickinger $v$ Crown Colony of Hong Kong, ${ }^{50}$ the New Zealand Court of Appeal appeared willing to rely on s 6 BORA to overturn a century-old interpretation of a procedural statute, which had been affirmed on numerous occasions (indeed as recently as five years before), and about which there was no uncertainty. In that case, the issue was whether the right of habeas corpus guaranteed by s 23(1)(c) BORA carried with it an inherent right to appeal against an adverse determination at first instance of a habeas corpus application. The relevant section dealing with appeals to the Court of Appeal (s 66 of the Judicature Act 1908) had been interpreted as not allowing such appeals where the matter related to criminal matters. In Flickinger it was argued that the provision was capable of being given a meaning consistent with an appeal right, in that no language in that section specifically excluded the possibility of an appeal in such matters, and that accordingly the previous case law on s 66 of the Judicature Act 1908 had to be abandoned. The Court of Appeal accepted the appellant's reading of s 66 of the 1908 Act (including a right to appeal). The Court noted that this reading of the provision had not been taken in previous cases because the "statutory context and history [of the provision] led to a different conclusion." 51 Yet, notwithstanding this, the Court held that in light of the consistency direction in s 6 BORA "if s 66 of the [1908 Act] can be given a meaning consistent with the rights and freedoms contained in the Bill of Rights, that meaning must be preferred." 52 In the end the Court assumed, without deciding, that s 66 embraced appeals in criminal matters such as habeas corpus but dismissed the appeal on the merits.

These comments on s 6 BORA suggested that the Court of Appeal might use s 6 in a bold way. However, not long after Flickinger, in Knight $v C I R,{ }^{53}$ in obiter dicta,

\footnotetext{
${ }^{48}$ Draft New Zealand Bill of Rights, cl 1: “This Bill of Rights is the supreme law of New Zealand, and accordingly any law (including existing law) inconsistent with this Bill shall, to the extent of the inconsistency, be of no effect.” See in regard to the history of the clause Butler \& Butler, The New Zealand Bill of Rights Act: a commentary (Lexis Nexis, Wellington, 2005) para 2.7.3- 2.7.7., 2.7.14., 2.7.15.

${ }^{49}$ (1987) AJHR I.14, p 8.

${ }^{50}$ [1991] 1 NZLR 439, [1990-92] 1 NZBORR 1 (CA).

${ }^{51}$ Flickinger v Crown Colony of Hong Kong [1991] 1 NZLR 439, 440 (CA).

${ }^{52}$ Flickinger v Crown Colony of Hong Kong [1991] 1 NZLR 439, 440 (CA).

${ }^{53}$ [1991] 2 NZLR 30 (CA).
} 
Hardie Boys $\mathrm{J}$ for the Court of Appeal suggested that it was unlikely that s 6 could be invoked other than in cases of "ambiguity or uncertainty". 54

Over time a firmer view that s 6 BORA has brought something new has emerged. Notwithstanding his dicta in Knight, Hardie Boys $\mathrm{J}$ a year later considered that the scheme of BORA demonstrated that it was "plainly Parliament's intention that the rights and freedoms affirmed by the Bill [of Rights] should be upheld unless there is clear legislative intention to the contrary." ${ }^{55}$ In Herewini $v$ Ministry of Transport, ${ }^{56}$ Cooke P regarded s 6 BORA as an "emphatic direction" to the courts by Parliament as to the proper role of rights and freedoms in the interpretation process. ${ }^{57}$

After fifteen years of implementing BORA the New Zealand courts are more alive to the fact that generally worded language should not be given its usual width of meaning if BORA- inconsistency would result. ${ }^{58}$ The result is that New Zealand courts usually start with a "s 6 BORA orientation" - that is a preference for beginning the analysis of a statutory interpretation problem having construed BORA first and only then turning to the other enactment. ${ }^{59}$ This orientation means that in many cases the court will have in the forefront of its mind the standards that an enactment must meet in order to ensure BORA consistency. That being the case, the court can approach the enactment largely free of preconceptions as to its literal meaning, focusing instead on the goal of achieving a BORA-consistent interpretation. Adopting this orientation ensures that judges see more possibilities for BORA consistent meanings than they would have, had the literal meaning of the other enactment been determined earlier.

\section{Limits of s 6 BORA interpretation}

At the same time, the Court of Appeal has consistently emphasised that the consistency direction in s 6 only authorises consistent meanings to be given to enactments where such a meaning can be "reasonably" 60 or "properly" 61 given;

\footnotetext{
${ }^{54}$ [1991] 2 NZLR 30, 42 (CA). The case concerned the question when disclosure of material fell within the exception of s 13(3) of the Inland Revenue Department Act 1974 which provided that departmental officers shall not be required to produce in Courts or tribunals any book or document, or to divulge or communicate with such Courts or tribunals any matter coming under his notice in the performance of his duties as an officer of the department, except when it is necessary to do so for the purpose of (inter alia) carrying into effect the Inland Revenue Acts. It has to be noted that Cooke P stated in an obiter dictum that if s 13(3) would have been in any way ambiguous the preferred interpretation for the purposes of this action against the Crown would have been against the claim for special privilege having regard to s 6 and s 27(3) of the New Zealand Bill of Rights Act 1990 (p 37).

${ }^{55}$ Ministry of Transport v Noort; Police v Curran [1992] 3 NZLR 260, 287 (CA).

${ }^{56}$ [1990-1992] 3 NZBORR 113, 139 (HC).

${ }^{57}$ Police v Herewini \& Smith [1994] 2 NZLR 306, 313 (CA). Cooke P wrote the dissenting judgment. The dissent was unrelated to the proper role of s 6 BORA.

${ }^{58}$ See, for example, Newspapers Publishers Association of New Zealand v Family Court [1999] 2 NZLR 344, 350, 351 in regard to the relationship between freedom of the press and the best interest of the child.

${ }^{59}$ Butler \& Butler, The New Zealand Bill of Rights Act: a commentary (Lexis Nexis, Wellington, 2005) para 7.10.4.

${ }^{60}$ Ministry of Transport v Noort; Police v Curran [1992] 3 NZLR 260, 272 (CA, Cooke P); Police v Herewini \& Smith [1994] 2 NZLR 306, 313 (CA, per Cooke P).

${ }^{61}$ Quilter v Attorney-General [1998] 1 NZLR 523, 581 (CA, Tipping J); Moonen $v$ Film and Literature Board of Review [2000] 2 NZLR 9 (CA) para 17; R v Hansen [2005] BCL 869 para 33.
} 
conversely, s 6 does not authorise a "strained" 62 interpretation. The BORA-consistent interpretation must be "fairly open" 63 and "tenable". 64 Section 6 does not authorise the rewriting of the law. ${ }^{65}$

But does s authorise judges to adopt a linguistically open meaning? In some cases, it has been held that it is not open to the courts to adopt a meaning that is clearly contrary to Parliament's intent. ${ }^{66}$ Accordingly, one judge has stated "even if a meaning is theoretically possible, it must be rejected if it is clearly contrary to what Parliament intended." ${ }^{67}$ That said, there are dicta that would contradict this last statement. So, for example, in $R v$ Poumako $^{68}$ three of the seven Court of Appeal judges who heard that case stated: "The meaning to be preferred is that which is consistent (or more consistent) with the rights and freedoms in the Bill of Rights. It is not a matter of what the Legislature (or an individual Member) might have intended." 69

That means when interpreting a provision in a BORA-consistent way the courts have to balance the goal of achieving reasonable interpretations of legislation to ensure human rights consistency, against a recognition that separation of powers means that Parliament and the Executive have a role to play in the human rights enterprise and may even choose to subjugate human rights consistency in favour of other interests. New Zealand case law shows how difficult this balance can be:

\section{1. $R v$ Phillips and $R v$ Hansen}

For example, in $R v$ Phillips $^{70}$ the Court of Appeal had to consider the interpretation of a provision in s 6 of the Misuse of Drugs Act 1975 (possession of 28 grams or more of cannabis plant to be deemed to be possession for supply, "until the contrary is proved"). The appellant argued relying on s 25(c) BORA (the right to be presumed innocent until proven guilty according to law) that the statutory phrase could be interpreted to mean "until some evidential foundation sufficient to create a reasonable doubt appears." The Court rejected the appellant's argument on the ground that it was contrary to the ordinary and natural meaning of the words, which were incapable of being strained in the manner suggested by counsel. The Court held that the ordinary and natural meaning of "proved" could not include evidence that was only sufficient to create a reasonable doubt as to guilt. ${ }^{71}$

\footnotetext{
${ }^{62}$ See, for example, Simpson v Attorney-General (Baigent's case) [1994] 3 NZLR 667, 674 (CA, Cooke P); $R$ v Phillips [1991] 3 NZLR 175, 177 (CA); Quilter v Attorney-General [1998] 1 NZLR 523, 542 (CA, Thomas J); $R v$ Hansen [2005] BCL 869 para 33 (CA).

${ }^{63}$ Ministry of Transport $v$ Noort; Police v Curran [1992] 3 NZLR 260, 286 (CA, Hardie Boys).

${ }^{64}$ Moonen v Film and Literature Board of Review [2000] 2 NZLR 9 (CA) para 16.

${ }^{65}$ Compare Tipping J in Quilter v Attorney-General [1998] 1 NZLR 523, 581 (CA): "We may interpret, be we cannot rewrite or legislate"

${ }^{66}$ Quilter v Attorney-General [1998] 1 NZLR 523, 541 (CA, Thomas J); Birch v MOT (1992) CRNZ 83, 85 (HC).

${ }^{67}$ Quilter v Attorney-General [1998] 1 NZLR 523, 542 (CA, Thomas J). However, see the discussion of $R v$ Poumako (2000) 5 HRNZ 652 (CA) below.

${ }^{68}$ (2000) 5 HRNZ 652.

${ }^{69} R$ v Poumako (2000) 5 HRNZ 652 para 37 (CA, Richardson P, Gault and Keith JJ).

${ }^{70}$ [1991] 3 NZLR 175 (CA).

${ }^{71}$ [1991] 3 NZLR 175, 176, 177 (CA).
} 
Last year the Court of Appeal revisited $R v$ Phillips in its decision $R v$ Hansen. ${ }^{72}$ The significance of the Court's decision lies in the fact that the House of Lords in $R v$ Lambert $^{73}$ had considered that in the equivalent provision to s 6 of the New Zealand Misuse of Drugs Act 1975 in the UK Misuse of Drugs Act 1971 the word "prove" meant "gives sufficient evidence". This interpretation was favoured in light of the presumption of innocence guaranteed by art 6(2) of the ECHR despite the fact that their Lordship had acknowledged that on the ordinary canons of construction the provision would be held to cast a legal burden on the accused. ${ }^{74}$ The Court of Appeal rejected the Lambert approach. Without considering the reasonableness of the reverse onus provision in s 6 of the Misuse of Drugs Act 1975, the Court held that "[t]he word 'proved' is fatal to [the accused's] argument". ${ }^{75}$ The Court stated that "[t]he idea of proof requires the party charged with the burden to show something to a persuasive standard....raising an issue as to a particular element of crime cannot be said to be 'proof'.,76 Instead of outright rejecting the Lambert decision the Court of Appeal distinguished the decision on the basis that the interpretative obligation under s 3(1) of the HRA 1998 went further that that imposed by s 6 BORA. ${ }^{77}$

\section{Baigent's case}

As mentioned earlier, one of the most famous cases under BORA is Baigent's case. ${ }^{78}$ It is famous for establishing a new cause of action founded on BORA that was public law in nature and created a direct, rather than a vicarious, liability as against the Crown in case of violation. ${ }^{79}$ However, the judges in Baigent also had to consider the scope of various statutory immunities given to police officers executing search warrants. Counsel for the plaintiffs argued that the statutory immunities had to be interpreted consistently with s 21 BORA, which protects the right to be free from unreasonable search and seizure. It was submitted that this right required that the apparently broad wording of the statutory immunities be read down so that unreasonable searches and seizures- even those carried out in good faith- could not enjoy the statutory immunities. The majority of the Court of Appeal rejected this submission. In his judgment, Cooke $\mathrm{P}$ accepted that the broad wording of the immunities made it legitimate for a court to assume that Parliament's intention was not to protect unreasonable act of police officers that were committed in bad faith; but the learned President refused to accede to the proposition that unreasonable searches and seizures carried out in good faith were not covered by the immunity. ${ }^{80}$

\footnotetext{
72 [2005] BCL 869 (CA).

73 [2002] 2 AC 545, [2001] 3 WLR 206 (HL).

${ }^{74} R$ v Lambert [2002] 2 AC 545 paras 10-14, 17, 18, 41-43, 84, 91, 94, 116, 117, 131, 147-148, 156157, 160, 169, 175-176, 199, 203.

${ }^{75} R v$ Hansen [2005] BCL 869 para 32 (CA).

${ }^{76} R v$ Hansen [2005] BCL 869 para 33 (CA).

${ }^{77} R$ v Hansen [2005] BCL 869 para 39 (CA).

${ }^{78}$ Simpson v Attorney-General [1994] 3 NZLR 667 (CA).

${ }^{79}$ See discussion of Baigent's case in Butler "Human Rights and Parliamentary Sovereignty in New Zealand” (2004) 35 VUWLR 341, 348- 350.

${ }^{80}$ Simpson v Attorney-General (Baigent's case) [1994] 3 NZLR 667, 674 (CA): “In this situation I think that the solution is dictated by s 6 of the New Zealand Bill of Rights Act 1990.... I accept that this legislative injunction does not extend to a strained meaning; but the principle that a generallyworded protection does not cover acts done in bad faith has respectable support: to apply it is not to strain. Taken together, ss 3 and 21 of the Bill of Rights Act affirm security against unreasonable search or seizure on behalf of the Executive Branch of Government of New Zealand (which must include the Police). It is consistent with that affirmed right to interpret s 6(5) of the Crown Proceedings Act as not
} 


\section{Quilter's case}

In Quilter v Attorney-General the Court of Appeal had to decide upon the question whether the Marriage Act 1955 could be interpreted to embrace same-sex couples. The Court was very clear that it could not rewrite the law contrary to Parliament's wish. An interpretation of the Marriage Act 1955 to include same-sex couples would assume the role of the lawmaker. ${ }^{81}$ Section 4 of the Bill of Rights says that Parliament has reserved to itself all legislative functions. ${ }^{82}$ Tipping J pointed out that on its enactment the Marriage Act was clear beyond doubt in the meaning which it attributed to the concept of marriage. The legislation passed after the enactment of the Bill of Rights supports that initial meaning. There is no basis therefore upon which the Marriage Act can (in terms of s 6) be interpreted as permitting same-sex marriage. The Court acknowledge that "[i]t is highly unlikely that Parliament would have intended to make such a substantial change to one of society's fundamental institutions by the indirect route of s 19 and s 6 of the Bill of Rights.” ${ }^{3}$

\section{4. $R v$ Poumako and $R v$ Pora}

The more recent judgments of the Court of Appeal in $R v$ Poumako ${ }^{84}$ and $R v$ Pora ${ }^{85}$ neatly illustrate the conundrum of a bill of rights informed statutory interpretation.

$R v$ Poumako was the first of two decisions dealing with the interpretation of the home invasion legislation passed in 1999. The issue revolved around whether a specific clause had retrospective effect. The difference between the two cases lay in the different periods at issue. The Court found it desirable for Parliament to reconsider the issue holding that the legislation was inconsistent with fundamental rights. ${ }^{86}$ It also has to be noted that the provision at issue was introduced later in the legislative process and was not subject to a section 7 report.

However, the majority (3:2) dealt with that issue only in an obiter dictum, specifically stating that they did not need to reach a final conclusion, basing its decision on other grounds. In the obiter dictum the majority found that it had never been Parliament's intent to afford retrospective effect to the home invasion provisions of the Crimes Act 1961. The judges interpreted the clause more narrowly, concluding that the section could be given retrospective effect only back to the date on which the home invasion amendments to the Crimes Act 1961 commenced. Even though that would still conflict with the principle against higher sentences than at the time of offending, this interpretation was the most consistent with the rights and freedoms prescribed in the BORA. ${ }^{87}$

protecting the Crown from liability for the execution of a search warrant in bad faith.... But it would be strained, ...to go further and hold that s 6(5) does not cover an unreasonable execution of a search warrant carried out in good faith. That seems to be an example of the very kind of vicarious liability which the subsection is intended to exclude”. See also 691 (Casey J), 696 (Hardie Boys J).

${ }^{81}$ Quilter v Attorney-General (1997) 4 HRNZ 170, 178 (Gault J), 223 (Tipping J).

${ }^{82}$ Quilter v Attorney-General (1997) 4 HRNZ 170, 223 (Tipping J).

${ }^{83}$ Quilter v Attorney-General (1997) 4 HRNZ 170, 232 (Tipping J), see also at 206 (Keith J).

${ }^{84}$ [2000] 2 NZLR 695, (2000) 5 HRNZ 652 (CA).

${ }^{85}$ [2001] 2 NZLR 37, (2000) 6 HRNZ 129 (CA).

${ }^{86} R$ v Poumako (2000) 5 HRNZ, 652, 665 [42], 672 [67], 683 [107] (per Richardson P, Gault, Keith, Henry, Thomas JJ).

${ }^{87}$ R v Poumako (2000) 5 HRNZ, 652, 664 [36]- 665[41] (per Richardson P, Gault, Keith JJ). 
The dissenting judges on the other hand found that the section in question was unambiguous and certain in its retrospective effect and, therefore, section 6 of the Bill of Rights Act could not be invoked to support an interpretation which was not Parliament's intent (having had a look at the parliamentary debates). ${ }^{88}$

In $R v$ Pora $^{89}$ the Court of Appeal, consisting of a seven judge bench, had to decide whether the 1999 amendment of the Criminal Justice Act, imposing a minimum of 13 years in detention where murder had been committed in the course of home invasion, would prevail retrospectively over the Criminal Justice Act 1985. In the latter Act Parliament had declared that no court could impose a retrospective penalty. It is important to note that all judges who dealt with the issue (Richardson P did not) agreed that the interpretative problem facing the court did not relate to the meaning of either provision. Both provisions were clear in their meaning. All agreed that because the meaning of the provisions in question was clear and the provisions were irreconcilable that one had to yield over the other. The Court divided three to three on whether a fundamental right can be impliedly repealed by later legislation. ${ }^{90}$

Three of the judges took the view that based on the long standing rule of implied repeal, the Court must apply the statute that was enacted later in time and, therefore, the 1999 amendment of the Criminal Justice Act 1985 had retrospective effect. ${ }^{91}$ Those judges acknowledged that their interpretation of the provision in question was a serious breach of a fundamental rule of New Zealand's legal and constitutional system and New Zealand's international obligations.

On the other hand, the other three judges held that the predominant intention of Parliament may be found in the earlier statute, except where there is an express statement that the later Parliament intended to cease protecting the fundamental rights in question. $^{92}$ They also pointed out that they were following Parliament's own intention, as manifested in s 6 of BORA, that "Parliament must speak clearly if it wishes to trench upon fundamental rights."93 Thomas J explicitly stated that where the courts are confronted with a difficult provision, "the Courts make do by filling the gap, if there be a gap, or by otherwise adopting an interpretation which accords with the purpose of the statute." ${ }^{94}$ Furthermore, they argued that through section 6 of the Bill of Rights Act Parliament had adopted a general principle of legality of the type acknowledged in a speech by Lord Hoffmann in $R v$ Secretary of State for the Home Department, ex parte Simms and other overseas case law. ${ }^{95}$ In his speech (referred to by the judges) Lord Hoffman acknowledged that parliamentary sovereignty meant that Parliament could legislate contrary to human rights. However, Parliament was

\footnotetext{
${ }^{88} R$ v Poumako (2000) 5 HRNZ, 652, 670 [57]-[58], 676 [80] (per Henry, Thomas JJ).

${ }^{89}$ (2000) 6 HRNZ 129. See for a critical case note on $R v$ Pora: Andrew Butler "Implied Repeal, Parliamentary Sovereignty and Human Rights in New Zealand” [2001] P.L. 586.

${ }^{90}$ Richardson P, as he then was, reserved his decision on that issue: $R$ v Pora (2000) 6 HRNZ 129, 147 [60].

${ }_{91}^{R}$ v Pora (2000) 6 HRNZ 129, 157 [110]- 158 [114] (per Gault, Keith, McGrath JJ).

${ }^{92} R$ v Pora (2000) 6 HRNZ 129, 139 [20], 141 [29], 145 [52]-[53], 146 [56], 162 [131], 167 [151] (per

Elias CJ, Tipping, Thomas JJ ).

${ }^{93} R$ v Pora (2000) 6 HRNZ 129, 145 [52], 160 [120] (per Elias CJ, Tipping, Thomas JJ).

${ }^{94} R$ v Pora (2000) 6 HRNZ 129, 160 [122].

${ }^{95} R$ v Pora (2000) 6 HRNZ 129, 145 [53]- 146 [56] (per Elias CJ, Tipping J).
} 
constrained by the principle of legality which meant that it had to "squarely confront what it is doing and accept political cost”. ${ }^{96}$

$R v$ Pora as well as $R v$ Poumako looked at the drafting history of the retrospective clause in the 1999 amendment. According to the judges, that history did not reveal any indication that Parliament appreciated that the adoption of the clause was inconsistent with the older provisions in the Criminal Justice 1985 which generally stated that courts could not impose sentences retrospectively, the Bill of Rights Act, and New Zealand's obligation under the International Covenant on Civil and Political Rights. The judges viewed that the doctrine of implied repeal meant that the provision in the amendment prevailed. Their Honours drew their conclusion from the text and the statement of the Member of Parliament promoting it $^{97}$ and concluded that "Parliament's word and purpose are, we consider, so plain that we do not think that the breach can be removed by judicial interpretation." 98 The other three judges held that it was ${ }^{99}$

\footnotetext{
"inconceivable that Parliament would have acted so casually had it appreciated the implications [of the inconsistency with fundamental rights]. In the circumstances we do not accept that it is proper to draw an inference from the temporal sequence of the legislation or from the more specific terms of s 2(4) that Parliament intended it to prevail."
}

$R v$ Pora amplifies the problem with s 6 BORA (or any consistency direction): it is in the end up to the individual judges when and how they interpret legislation and how they interpret Parliament's intent. Both might also depend on the judges' understanding of parliamentary sovereignty. Especially in recent years New Zealand jurists have stated that Parliament's sovereignty is not without limits. Sir Robin Cooke (as he then was) suggested that the operation of a democratic legislature and the operation of independent courts should be seen as the two pillars of a free and democratic society. ${ }^{100}$ He said that:

[I]f a change, by legislation or otherwise, were seen to undermine either of them to a significant extent, it would be the responsibility of the Judges to say so and, if their judgments to that effect were disregarded, to resign or to acknowledge frankly that they are prepared to depart from their judicial oath and to serve a state not entitled to be called a free democracy.

Therefore, depending on the judge's understanding on his or her role in the government triangle he or she might follow the three judges in Pora who could not fathome that Parliament could enact legislation so clearly inconsistent with fundamental rights or the judges who drew on the wording of the provision and the comments made during the parliamentary debate to reach a conclusion in regard to Parliament's intent.

\footnotetext{
${ }^{96} R v$ Secretary of State for the Home Department, ex parte Simms [2000] 2 AC 115, 131.

${ }^{97} R$ v Pora (2000) 6 HRNZ 129, 157 [107] (per Gault, Keith, McGrath JJ).

${ }^{98} R$ v Pora (2000) 6 HRNZ 129, 159 [116] (per Gault, Keith, McGrath JJ).

${ }^{99} R$ v Pora (2000) 6 HRNZ 129, 145 [48] (per Elias CJ, Tipping J). As mentioned earlier by promoting the provision concerns in regard to its compliance with fundamental rights were raised.

${ }^{100}$ Cooke "Fundamentals" [1988] NZLJ 158, 164. See also Elias "Sovereignty in the $21^{\text {st }}$ Century: Another Spin on the Merry-Go-Around” (2003) 14 PLR 148.
} 


\section{What lessons can be learned from New Zealand?}

The New Zealand experience shows that a dialogue between the three arms of government is possible. The parliamentary bill of rights model seems to achieve a dialogue where each arm of government participates in developing a better understanding and compliance with human rights. However, a parliamentary bill of rights model does not always maximise human rights protection. After all it took the New Zealand Parliament six months after the Court of Appeal had held in Poumako that the retrospective clause in question was not BORA compliant to repeal that provision. And it did take eight years to enact the Civil Union Act 2005 which in the eyes of many is not an ideal solution either since it does not allow for homosexuals to be married. $^{101}$

In regard to the way the New Zealand courts have worked with s 6 BORA, it has to be observed that they still have not developed criteria to find the balance when to interpret BORA consistent and when treating in the realm of Parliament. However the courts have not used s 6 BORA to usurp the role of Parliament in regard to lawmaking. In fact, statements such as those in Quilter ${ }^{102}$ suggest that the courts are very aware that s 6 BORA does not give them the licence to play legislature.

\section{Postscriptum}

I would like to take the opportunity to comment on some of the comments made during the Conference.

The Chief Minister stated that he wished the judges and the lawyers were more active in helping to give the ACT HRA more of a profile by bringing more cases in front of the courts and for the courts to take every opportunity to use the ACT HRA. New Zealand was very fortunate that already at the birth of BORA there were committed judges, like Lord Cooke, and lawyers who saw BORA's potential for their work and used BORA relentlessly. Also the establishment of a law report series just two years after its coming into force gave BORA a good profile. ${ }^{103}$ For many years the New Zealand Law Society had a Human Rights Committee analysing human rights concerns. However, it has to be borne in mind that even after 15 years of its existence BORA arguments are still avoided or not fully explored. ${ }^{104}$ And anecdotal evidence suggests that commercial lawyers are still not switched on to the potential relevance of BORA to their work ${ }^{105}$.

\footnotetext{
${ }^{101}$ See for a critique Austin "Essay: Family Law and Civil Union Partnerships - Status, Contract and Access to Symbols” (2006) 37 VUWLR (forthcoming).

102 See above pp 8, 9.

103 The first law report specialised on BORA cases was New Zealand Bill of Rights Reports (NZBORR) (editors: Andrew Butler, Antony Shaw) which later became the Human Rights Reports of New Zealand (HRNZ).

104 See, for example, Dunne v Canwest TVWorks Ltd (C IV 2005495 1596) (HC Wellington, 11.08.2005): the case involved two Members of Parliament who wanted to take part in election special hosted by TV 3. Neither counsel for plaintiff nor respondent argued the relevant BORA rights (like freedom of speech, electoral rights or even s 3 BORA which defines to whom BORA applies).

105 Richardson "The New Zealand Bill of Rights: experience and potential including the implications for commerce" (2004) 10 Canterbury L Rev 259.
} 
How far the environment has changed in the last 15 years can be seen in the fact that last year the Human Rights Commission published a National Plan of Action for Human Rights ${ }^{106}$ after widely consulting with the New Zealand public but also with stakeholders about the status of human rights in New Zealand. For the first time New Zealand's citizens were asked whether they felt that New Zealand was honouring their human rights. Furthermore, the Ministry of Justice was the host of a conference at the beginning of this year celebrating 15 years of BORA. ${ }^{107}$

${ }^{106}$ Available on http://www.hrc.co.nz (last accessed 27.06.2006).

${ }^{107}$ Publication of the conference papers is forthcoming. 